DOI : $10.15393 /$ j9.art.2008.275

Е. Н. Монахова

Санкт-Петербург

\title{
«ТАК, ТЫ ПРАВ, ОРАКУЛ ФРАНЦИИ...» ПОЭМА А. С. ПУШКИНА «РУСЛАН И ЛЮДМИЛА» В КОНТЕКСТЕ РУССКОЙ ИСТОРИИ ЭПОХИ ОТЕЧЕСТВЕННОЙ ВОЙНЫ 1812 ГОДА
}

Восходит к смерти Людовик В виду безмолвного потомства, Главой развенчанный приник К кровавой плахе вероломства. А. С. Пушкин. «Вольность»

Вдруг холм, безоблачной луною В тумане бледно озарясь, Яснеет; смотрит храбрый князь И чудо видит пред собою. Найду ли краски и слова? Пред ним живая голова.

А. С. Пушкин. «Руслан и Людмила»

Поэму «Руслан и Людмила», работу над которой А. С. Пушкин начал в лицейские годы, а завершил в Петербурге, в 1820 году, накануне южной ссылки, исследователи трактовали в основном либо как произведение эпического жанра, связанного неразрывно с фольклорными, сказочными мотивами (причем не только русскими, но также европейскими и восточными), либо как произведение романтического плана, а также связывали ее появление непосредственно с театральными впечатлениями поэта трех лет его петербургской жизни.

(C) Монахова Е. Н., 2008 
Существует поистине гигантская библиография по данному вопросу. Отметим, что почти никто из авторов, посвятивших поэме «Руслан и Людмила» свои статьи и книги, не имел задачи сопоставить образы ее, сюжетные коллизии, отдельные эпизоды с современными Пушкину историческими событиями и конкретными историческими лицами.

Именно такую задачу я решаюсь поставить в настоящей работе.

Не существует двух мнений в вопросе о том, сколь огромное действие на душу юного поэта-лицеиста Александра Пушкина имело наполеоновское нашествие на Россию. В книге Ю. М. Лотмана о Пушкине резюмируется общее убеждение:

Bce мемуаристы единодушны в описании и оценке огромного впечатления, которое произвели на Лицей и лицеистов события 1812 года. Сошлемся... на Пущина. «Жизнь наша лицейская сливается с политическою эпохою народной жизни русской: приготовлялась гроза 1812 года. Эти события сильно отразились на нашем детстве Началось с того, что мы провожали все гвардейские полки, потому что они проходили мимо самого Лицея».

Впечатления этих лет, конечно, определили гражданский пафос и раннее свободомыслие многих лицеистов, включая и Пушкина. Однако события действовали на молодые умы еще в одном отношении: История со страниц учебников сама явилась на лицейский порог. Для того чтобы обессмертить свое имя и передать его потомкам, уже не нужно было родиться в баснословные времена или принадлежать к семье коронованных особ. Не только «муж судеб», сын мелкого корсиканского дворянина Наполеон Бонапарте, сделавшийся императором Франции и перекраивавший карту Европы, но и любой из молодых гвардейских офицеров, проходящих мимо 
ворот Лицея, чтобы пасть под Бородином, Лейпцигом или на высотах Монмартра, был «человеком истории» ${ }^{1}$.

В лицейские годы А. Пушкиным были созданы произведения, где события, потрясшие мир, описывались гневными и страстными строфами буквально сразу после их свершения - это стихотворения «Наполеон на Эльбе», «Александру», «Принцу Оранскому» и самое раннее из них:

\footnotetext{
${ }^{1}$ Лотман Ю. М. Александр Сергеевич Пушкин. Биография
} писателя: Пособие для учащихся. Л.: Просвещение, 1981.

248

«Воспоминание в Царском Селе». Можно легко представить, что из летописи страшных катаклизмов той поры одно событие особенно поразило автора, урожденного москвича - пожар древней столицы русских царей.

Края Москвы, края родные,

Где на заре цветущих лет

Часы беспечности я тратил золотые,

Не зная горестей и бед,

И вы их видели, врагов моей отчизны!

И вас багрила кровь и пламень пожирал!

И в жертву не принес я мщенья вам и жизни;

Вотще лишь гневом дух пылал!..

В этих строках, прочитанных перед будущим митрополитом Московским Филаретом (Дроздовым) и Гавриилом Державиным, бьются подлинные боль и гнев.

Наполеоновские войны, нашествие на Россию, пожар Москвы, Бородинское сражение, взятие Парижа русской армией, изгнание Бонапарта на остров Эльба, Сто дней, вторичное изгнание на затерянный в океане остров Святой Елены и, наконец, смерть бывшего властителя полумира, а также предшествующие им события - 
взятие Бастилии, Великая французская революция, казнь Людовика XVI и Марии-Антуанетты - потрясали современников.

В первый день Святой Пасхи, 29 марта 1813 года, Париж стал свидетелем удивительного события. Император Александр так описал его в беседе с князем А. Н. Голициным:

Еще скажу тебе о новой и отрадной для меня минуте в продолжение жизни моей: я живо тогда ошущал, так сказать, апофеоз русской славы между инопленниками, я даже их самих увлек и заставил разделять с ними национальное торжество наше. Это вот как случилось. На то место, где пал кроткий и добрый Людовик XVI, я привел и поставил своих воинов; по моему приказанию сделан был амвон, созваны были все русские священники, которых только найти можно, и вот, при бесчисленных толпах парижан всех состояний и возрастов, живая гекатомба наша вдруг огласилась громким и стройным русским пением... Все замолкло, все внимало!.. Торжественная была эта минута для моего сердца; умилителен, но и страшен был для меня момент этот. Вот, думал я, по неисповедимой воле Провидения, из холодной отчизны Севера привел я православное русское мое воинство для того, чтобы

${ }^{2}$ Пуикин А. С. Полн. собр. соч. М.; Л.: Изд-во АН СССР, 1950. T. 1. C. 73 .

на земле иноплеменников, столь недавно еще нагло наступавших на Россию, в их знаменитой столице, на том самом месте, где пала царственная жертва от буйства народного, принесли совокупную, очистительную и вместе торжественную молитву Господу. Сыны Севера совершали как бы тризну по королю Французскому. Русский царь по ритуалу православному всенародно молился со своим народом и тем как бы очищал окровавленное место пораженной царственной жертвы. Духовное наше торжество в полноте достигло своей цели; оно невольно втолкнуло благоговение и в самые сердца 
французские. Не могу не сказать тебе, Голицин, хотя это и несовместимо в теперешнем рассказе, что даже забавно было видеть, как французские маршалы, как многочисленная фаланга генералов французских теснилась возле русского креста и друг друга толкала, чтобы иметь возможность скорее к нему приложиться. Так обаяние было повсеместно, так оторопели французы от духовного торжества русских ${ }^{3}$.

События рубежа двух столетий были так значительны, глобальны, можно сказать, апокалиптичны, что есть все основания предполагать: отклик поэта на них - впрямую коснувшихся его лично разрушением города детства заключался не только в известных стихотворениях и отдельных фрагментах, но и прозвучал во всем творчестве А.С. Пушкина, вдохновив его в лицейские еще годы на большое произведение эпического жанра такое, каким является романтическая поэма.

Следует сказать, что сам автор не отзывался ни об одной из своих поэм (и сказок!) как о попытке в завуалированной, символической форме изобразить недавнюю историю, при том что в ранней лицейской поэме «Бова» имеются прямые указания на события во Франции, предшествующие наполеоновским войнам. Но об этом ниже.

Я рискую предположить, что основным откликом нашего национального поэта, а таковым Пушкин ощутил себя уже в последние лицейские годы (после встреч с Карамзиным, Державиным, Жуковским), на мировые катаклизмы, захватившие и Россию, была его поэма «Руслан и Людмила».

Но прежде чем пытаться обосновать такую точку зрения, обращаюсь к другому произведению неоконченной лицейской поэме Пушкина «Бова», в которой трагическая история французской королевской династии является предметом повествования, правда, в стиле древнерусского сказания 
${ }^{3}$ Тальберг Н. Д. Александр І. Очерки истории Императорской России. М.: Изд-во Сретенского монастыря, 2001. С. 105-106.

250

или былины, с соответствующим антуражем, именами и названиями.

Тут все предельно прозрачно - своим вдохновителем автор выбирает не Бояна, не Леля, а совсем иное, казалось бы, неожиданное в данном контексте лицо:

О, Вольтер! О муж единственный!

Ты, которого во Франции

Почитали богом некиим,

В Риме дьяволом, антихристом,

Обезьяною в Саксонии!

Ты, который на Радищева

Кинул было взор с улыбкою,

Будь теперь моею музою! ${ }^{4}$

Автор, обращаясь к Вольтеру, за пример для себя берет его знаменитое творение, чтобы повествовать о «Светомире, сильном городе», где «царь Дадон со славой царствовал»:

...Вчера, в архивах рояся,

Отыскал я книжку славную, Золотую, незабвенную,

Катехизис остроумия,

Словом: Жанну Орлеанскую.

Прочитал, — и в восхищении

Про Бову пою царевича ${ }^{5}$.

В конце короткой поэмы Пушкин опять вспоминает Вольтера:

Так, ты прав, оракул Франции,

Говоря, что жены, слабые

Против стрел Эрота юного, 
Все имеют душу добрую,

Сердце нежно непритворное 6 .

Что касается героев «Бовы» и их приключений, то и здесь Пушкин не оставляет места сомнению, прямо указывая, на кого они похожи.

Не запомню, сколько лет спустя

После Рождества Спасителя,

\footnotetext{
${ }^{4}$ Пушкин А. С. Полн. собр. соч. Т. 1. С. 61. Хочу упомянуть здесь, что одноименная поэма А. Н. Радищева «Бова», им не законченная, создававшаяся по возвращении из Сибири в царствование Павла I, впоследствии трактовалась некоторыми исследователями в духе исторической символики: под Дадоном подразумевался Петр I.

${ }^{5}$ Там же. С. 60.

${ }^{6}$ Там же. С. 68
}

Царь Дадон со славой царствовал

В Светомире, сильном городе.

Царь Дадон венец со скипетром

Не прямой достал дорогою,

Но убив царя законного,

Бендокира Слабоумного,

Так бывало верноподцанны

Величали королей своих,

Если короли беспечные,

Не в постеле и не ночкою

Почивали с камергерами.

Царь Дадон не Слабоумного

Был достоин злого прозвища,

Но тирана неусыпного,

Хотя, впрочем, не имел его.

Лень мне все его достоинства

И пороки вам показывать:

Вы слыхали, люди добрые,

О царе, что двадцать целых лет

Не снимал с себя оружия, 
Не слезал с коня ретивого,

Всюду пролетал с победою,

Мир крещеный потопил в крови,

Не щадил и некрещеного,

И в ничтожество низверженный

Александром, грозным ангелом,

Жизнь проводит в унижении

И, забытый всеми, кличется

Ныне Эльбы императором:-

Вот таков-то был и царь Дадон ${ }^{7}$.

Итак, «Бова»—- это поэма об узурпации власти законного властителя - Бендокира Слабоумного, и совершенно ясно, что здесь имеется в виду погибший на гильотине Людовик XVI, а самозванец Дадон напрямую сопоставляется с Наполеоном. Исторически в этом нет полного соответствия, так как Бонапарт непосредственно никак не был виновен в казни французского короля - он лишь пришел занять его освободившийся трон, будучи подброшен к нему волной революции. Но при этом вся Европа считала (и называла!) его в то время узурпатором законной королевской власти во Франции.

В поэме А. С. Пушкина Дадон боится за свой трон и держит в тюрьме сына Бендокира Бову, о котором сказано как бы на двух языках:

${ }^{7}$ Там же. С. 66.

252

.... в темницу посадил Бову,

Принца крови, сына царского ${ }^{8}$.

Известно, что наследник Людовика XVI и МарииАнтуанетты после казни родителей был отдан учиться сапожному мастерству и умер через два года. 
В «Руслане и Людмиле» тема узурпированной власти присутствует как история двух братьев: богатыря и карлика-колдуна.

Но Пушкин, в «Бове» буквально декларировавший сходство своих персонажей с героями исторической драмы, здесь делает все, чтобы увести читателей от прямых аналогий.

Поэма начинается словами, как бы исключающими всякую возможность трактовать ее сюжет в соответствии со злобой дня:

Дела давно минувших дней,

Преданья старины глубокой 9 .

Если вспомнить, что во время патриотического подъема, вызванного наполеоновским вторжением и последовавшим скорым и позорным изгнанием французов из России, эпизоды героической истории воспринимались современниками Пушкина исключительно как напоминание о событиях близких и даже сиюминутных, то пушкинские строки могут быть восприняты как прямой намек на то, что действие только что совершилось.

В качестве примера приведу отрывки из воспоминаний современников. Вот свидетельство декабриста князя С. Г. Волконского, который в старости писал:

Поражение аустерлицкое, поражение фридландское, тильзитский мир, надменность французских послов в Петербурге, пассивный вид Александра перед политикой Наполеона I, - были глубокие раны в сердце каждого русского... Литература воспевала, выясняла всякую особенность патриотических прежних событий отечественных. Живо помню я, с каким восторгом, с каким громом рукоплесканий принимались некоторые места озеровской трагедии «Димитрий Донской». Стихи: «Российские князья, бояре, воеводы... Доколе было нам в отечестве своем терпеть 
татаров власть и в униженной доле рабами их сидеть!.. Ах! Лучше смерть в бою, чем

${ }^{8}$ Там же. С. 63. Подчеркнуто мною.

${ }^{9}$ Пушкин А. С. Полн. собр. соч. Т. 6. С. 13.

мир принять бесчестный»- бывали покрыты рукоплесканиями, подобно грому; театр, можно сказать, трещал от них ${ }^{10}$.

Юный театрал С. П. Жихарев еще выразительнее в своих описаниях:

Я просил у Дмитревского, читал ли он новую трагедию Озерова. - Слышал ее раза два, - отвечал он, - и сверх того видел ее репетицию на сцене. Нечего сказать, трагедия прекрасная и так пришлась теперь кстати: много превосходных патриотических стихов, которые публика, конечно, не оставит применить к настоящим обстоятельствам ${ }^{11}$.

И вот настает день премьеры.

Вчера, по возвращении из спектакля, я так был взволнован, что не в силах был приняться за перо, да признаться и теперь еще опомниться не могу от тех ощущений, которые вынес с собою из театра. Боже мой! Боже мой! Что это за трагедия «Димитрий Донской» и что за Димитрий - Яковлев! Какое впечатление производил этот человек на публику - это непостижимо и невероятно! Я сидел в кресле и не могу отдать отчета в том, что происходило. Я чувствовал стеснение в груди; меня душили спазмы, била лихорадка, бросало то в озноб, то в жар; то я плакал навзрыд, то аплодировал из всей мочи, то барабанил ногами по полу - словом, безумствовал, как безумствовала, впрочем, вся публика, до такой степени многочисленная, что буквально некуда было уронить яблока ${ }^{12}$.

Вряд ли нужны доказательства тому, что в эпоху великих потрясений (будь то война, революция или подобные им события) обостряются с необычайной силой 
патриотические чувства и тогда любое произведение историческое, сказочное, эпическое, драматическое воспринимается публикой особенно чутко в свете происходящего.

Первая критика «Руслана и Людмилы», рассмотренная самим автором в «Предисловии ко второму изданию поэмы», показывает, как внимательно современники вчитывались в ее текст - и искали в нем загадки и скрытые символы. Пушкин повторяет «вопросы неизвестного», которые низвергаются бурным потоком:

\footnotetext{
${ }^{10}$ Жихарев С. П. Записки современника. Дневник чиновника / Ред., коммент. и вступ. ст. С. Я. Штрайха. Т. ІІ. Воспоминания старого театрала. Письма. М.; Л.: Academia, 1934. С. 467-468.

${ }^{11}$ Там же. С. 17.

${ }^{12}$ Там же. С. 31.

254

...зачем маленький карла с большою бородою (что, между прочим, совсем не забавно) приходил к Людмиле? Как Людмиле пришла в голову странная мысль схватить с колдуна шапку (впрочем, в испуге чего не наделаешь?) и как колдун позволил ей это сделать $?<\ldots>$

Так ли говорили русские богатыри? И похож ли Руслан, говорящий о траве забвенья и вечной темноте в р е м е н, на Руслана, который через минуту после восклицает сважностью сердитой :
}

$$
\begin{aligned}
& \text { Молчи, пустая голова! } \\
& \text { Хоть лоб широк, да мозгу мало! } \\
& \text { Я еду, еду, не свищу! } \\
& \text { А как наеду, не спущу! } \\
& \text { <... Знай наших! и проч.? }
\end{aligned}
$$

Зачем Черномор, доставши чудесный меч, положил его на поле, под головою брата? Не лучше ли бы было взять его 
домой?

Зачем будить двенадцать спящих дев и поселять их в какуюто степь, куда, не знаю как, заехал Ратмир? Долго ли он пробыл там? Куда поехал? Зачем сделался рыбаком? Какая такая его новая подруга? Верно ли, что Руслан, победив Черномора и пришел в отчаяние, не находя Людмилы, махал до тех пор мечом, что сшиб шапку с лежащей на земле супруги?

Зачем карла не вылез из котомки убитого Руслана? Что предвещает сон Руслана? Зачем это множество точек после стихов:

\section{Шатры белеют на холмах?}

Зачем, разбирая Руслана и Людмилу, говорить об Илиаде и Энеиде? Что есть общего между ними? ${ }^{13}$

Следом за перечислением «вопросов неизвестного» Пушкин приводит колоритнейший отзыв из «Вестника Европы» (1820. № 11), подписанный «Житель Бутырской слободы» (под этим псевдонимом скрывается А. Г. Глаголев).

Автор «благономеренной статьи» особенно отмечает русскость, национальность - и даже архаику новоявленного творения:

Позвольте спросить: если бы в Московское благородное собрание как-нибудь втерся (предполагаю невозможное возможным) гость с бородою, в армяке, в лаптях, и закричал бы зычным голосом: здорово ребята! Неужели стали бы таким проказником любоваться? ${ }^{14}$

\footnotetext{
${ }^{13}$ Пушикин А. С. Полн. собр. соч. Т. 6. С. $485-493$.

${ }^{14}$ Там же. С. 490.
}

Особенно чувствительно задевает бутырского жителя сцена с головой: 
...но вот, что всего драгоценнее: Руслан наезжает в поле на побитую рать, видит богатырскую голову, под которою лежит меч-кладенец; гол ов а с ним разглагольствует, сражается. .. Живо помню, как все это, бывало, я слушал от няньки моей; теперь на старости сподобился вновь то же самое услышать от поэтов нынешнего времени!.. ${ }^{16}$

Итак, гигантская отрубленная голова, коварно отсеченная братом, злодеем и колдуном.

В «Бове» за королем (или царем?!) Бендокиром Слабоумным явственно сквозит образ несчастного французского короля, а про узурпатора его трона, коварного царя Дадона, сказано, что от точно такой же, как и Наполеон Бонапарт. В «Руслане и Людмиле» такая же коллизия: могучий законный владыка (или богатырь), коварно лишенный головы и власти... подкравшимся... карликом (или колдуном).

Изображения отрубленной человеческой головы (всегда одной и той же)- изображение казни во множестве мелькало в конце XVIII - начале XIX века перед читателями и зрителями со страниц книг, с гравюрных листов, с лубочных картинок.

Публичная казнь через усекновение головы, а позднее - гильотинирование - была повсеместно принята в Европе и широко распространена. Казнь Пугачева на Болотной площади в Москве, кстати, происшедшая ровно за восемнадцать лет до казни Людовика XVI тоже 21 января, не изгладилась из памяти русского общества ко времени Великой французской революции. А за памятью о пугачевской казни маячили легендарные массовые казни Петровской эпохи.

В творчестве А. С. Пушкина это отразится позднее но с необычайной экспрессией в поэме «Полтава»: уникальная по силе выражения, жуткая и напряженнотрагическая сцена казни Искры и Кочубея. 
...по киевской дороге

Телега ехала. В тревоге

Все взоры обратились к ней.

В ней, с миром, с небом примеренный,

Могущей верой укрепленный,

Сидел безвинный Кочубей,

С ним Искра тихий, равнодушный,

${ }^{15}$ Там же. С. 489.

256

Как агнец, жребию послушный.

Телега стала. Раздалось

Моленье ликов громогласных.

И кадил куренье поднялось.

За упокой души несчастных

Безмолвно молится народ,

Страдальцы за врагов. И вот

Идут они, взошли. На плаху,

Крестясь, ложится Кочубей.

Как будто в гробе, тьмы людей

Молчат. Топор блеснул с размаху,

И отскочила голова.

Все поле охнуло. Другая

Катится вслед за ней, мигая.

Зарделась кровию трава -

И, сердцем радуясь во злобе,

Палач за чуб поймал их обе

И напряженною рукой

Потряс их обе над толпой.

Свершилась казнь. Народ беспечный

Идет, рассыпавшись, домой

И про свои заботы вечны

Уже толкует меж собой.

Пустеет поле понемногу ${ }^{16}$.

Думается, подобный образ преследовал и мучил автора много лет- и во время процесса над декабристами, 
приговоренными вначале к четвертованию (а значит, и к отсечению головы). Последнюю казнь Пушкин, как видно из рисунков и надписей к ним в его черновиках, примерил и на себя:

$$
\text { И я бы мог, как шут... }
$$

Но возвратимся к «Руслану и Людмиле».

Самой знаменитой отсеченной головой «безумного и мудрого», по выражению А. Н. Радищева, «осьмнадцатого века», несомненно, была голова представителя древней династии французских королей, титулы которого не уместились бы на нескольких страницах, кровного родственника всех европейских монархов, правнука самого блистательного, самого легендарного из них, прозванного «королем-солнцем» (вспомним пушкинский город Светомир в поэме «Бова»!), казнь которого в Париже была подобна (по общественному резонансу во всем мире) извержению вулкана, мощному землетрясению, - Людовика XVI.

${ }^{16}$ Там же. С. 285.

При отсечении ее качнулись троны, прочно стоявшие в течение веков.

Описывая казнь, родной внук ее исполнителя, парижский потомственный палач Г. Сансон, так оценивал событие:

Теперь на очереди жертва, занимающая великое место в истории человечества... ${ }^{17}$

Подробности казни, вскоре ставшие известными по всей Европе, потрясали воображение.

...c позднего вечера Людовик беседовал с духовником. Ночью он крепко спал. В пять часов его разбудили. Утром он 
причастился и продолжал беседовать с духовником, и молился. В 8 часов утра за королем приехали. Людовик передал свое завещание, а также сверток с деньгами. Это был его долг адвокату, он не решился на еще одну встречу с семьей.

Карета со смертником, выехав из ворот Тампля, покатила по безлюдным улицам к площади революции, где была сооружена гильотина. Всю дорогу следования Людовик был спокоен. Он читал предсмертные молитвы.

На площади все было готово к казни. Казнить Людовика должен был палач Сансон, предки которого в семи поколениях были палачами. Перед тем, как взойти на эшафот, король снял камзол. Палачи хотели связать его, но Людовик стал сопротивляться. После того, как священник напомнил ему, что, когда связывали Христа, тот не сопротивлялся, Людовик успокоился. Взойдя на эшафот, бывший король обратился к своему народу: «Я умираю невиновным, я прощаю моим врагам и желаю, чтобы моя кровь пролилась на пользу французам». <..>

В десять часов затрещали барабаны на площади. Шесть палачей схватили Людовика, который отчаянно сопротивлялся, и привязали его к доске. В 10 часов 10 минут тяжелый топор гильотины падает. Палач показывает отрубленную голову короля народу. В толпе возглас - «Да здравствует Республика!» Народ подходил к эшафоту и обмакивал свои платочки в крови короля. Палач Сансон отрезал часть волос короля и впоследствии продавал их наряду с частичками его камзола. Неизвестный гражданин взошел на эшафот, зачерпнул целую горсть и оросил ею толпившихся людей. «Братья, сказал он, - нам ли угрожали, что кровь Капета падает на наши головы! Пусть же исполнится это пророчество, ведь король столько раз обагрял руки в нашей крови! Республиканцы! Кровь короля приносит счастье!» Король

\footnotetext{
${ }^{17}$ Сансон Г. Записки палача, или Политические и исторические тайны Франции. Луганск, 1993. Кн. 2. С. 118.
}

258

был не только казнен, но и унижен. Пушка, которая должна 
была возвестить о смерти Людовика, не выстрелила. Решили, что голова короля, падая, не должна произвести больше шума, чем любая другая голова. Труп короля зарыли в слое негашеной извести... ${ }^{18}$

В России о случившемся узнали через несколько дней. Потрясенный полученным из Парижа известием, поэт Державин создает почти одновременно два произведения совершенно разного стиля. Первое - эпитафия. «На смерть собачки Милушки, которая при получении известия о смерти Людовика XVI упала с колен хозяйки и убилась до смерти» 1793 года.

Увы! Сей день с колен Милушка

И с трона Людвиг пал. - Смотри,

О смертный! Не все ль судеб игрушка -

Собачки и цари?

Второе - стихотворение «Колесница», являющееся непосредственным откликом поэта на революционные события во Франции и начатое после получения в Петербурге 31 января 1793 года известия о казни Людовика XVI. Опубликовано оно было впервые только в 1804 году отдельным изданием без указания даты в журнале «Друг просвещения» (1804. Ч. III. С. 8).

Последние строки Державин в публикации опустил:

Увы! Доколе слышны стоны

И во крови земля кипит,

Ревут пожара страшны волны?

Или предел их небом скрыт? ${ }^{19}$

Стихотворение было переработано автором через несколько лет под влиянием известия о казни по приказу Наполеона герцога Энгиенского (1804). В «Друге просвещения» оду сопровождало примечание:

...не было бы удивительно, если бы несчастье Франции произошло от софистов или суемудрых писателей, а также от 
поступков злобного государя; но когда народ был просвещен истинным просвещением и правительство было кроткое, то загадка сия принадлежит к разрешению глубокомысленных политиков.

В допожарной Москве, в особняке родственника родителей А. С. Пушкина графа Мусина-Пушкина на Разгуляе

\footnotetext{
${ }^{18}$ Цит. по: Фетищев С. Последние дни господина Капета // Смена. 1993. № 13.21 янв. С. 5.

${ }^{19}$ Держсавин Г. Р. Соч. СПб.: Изд. Импер. АН, 1864. Т. І. С. 524531.
}

(где хранилось, к слову сказать, «Слово о полку Игореве») состоялась, как мы теперь говорим, «презентация», то есть публичное чтение стихотворения Державина, тогда еще не опубликованного. Писец, специально нанятый, во множестве экземпляров скопировал текст для раздачи всем желающим. Можно не сомневаться, что один из таких экземпляров был и у отца поэта, и у его брата Василия Львовича Пушкина. Оно, разумеется, с самого раннего возраста было известно и будущему автору «Руслана и Людмилы».

В державинской «Колеснице» есть прямое сопоставление образа несчастного возницы-короля, выпустившего из рук вожжи, и «безумной воли» того, кто принес в жертву своему властолюбию мчащуюся колесницу, то есть народ, нацию. Образ Наполеона, уничтожившего Французскую республику, маячит за строками стихотворения, созданого в далекой России.

В поэме А. С. Пушкина гигантская голова, застывшая как в странном сне (вспомним тень Бендокира Слабоумного в «Бове»), пробужденная потом Русланом, горестно повествует о своем несчастье: 
Достоин плача жребий мой.

И я был витязь удалой!

В кровавых битвах супостата

Себе я равного не зрел;

Счастлив, когда бы не имел

Соперником родного брата!

Коварный, злобный Черномор,

Ты, ты всех бед моих виною!

Семейства нашего позор,

Рожденный карлой, с бородою,

Мой дивный рост от юных дней

Не мог он без досады видеть

И стал за то в душе своей

Меня, жестокий, ненавидеть.

Я был всегда немного прост,

Хотя высок: а сей несчастный,

Имея самый глупый рост,

Умен как бес - и зол ужасно.

Притом же, знай, к моей беде,

В его чудесной бороде

Таится сила роковая,

И, все на свете презирая, -

Доколе борода цела -

Изменник не страшится зла.

Вот он однажды с видом дружбы «Послушай, - хитро мне сказал, Не откажись от важной службы: Я в черных книгах отыскал, Что за восточными горами На тихих моря берегах, В глухом подвале, под замками Хранится меч - и что же? страх! Я разобрал во тьме волшебной, Что волею судьбы враждебной Сей меч известен будет нам; Что нас он обоих погубит: 
Мне бороду мою отрубит,

Тебе главу: суди же сам,

Сколь важно нам приобретенье

Сего созданья злых духов!»

Наконец, меч найден. Но начинается раздор за право им обладать.

Меж нами ссора закипела -

И было, признаюсь, о чем!

Вопрос: кому владеть мечом?

Я спорил, карла горячился... ${ }^{20}$

Символика образов в этой сцене сопоставима с державинскими: у Пушкина власть олицетворяется в волшебном мече, у Державина это бразды правления колесницей.

Потрясает в «Руслане и Людмиле» сцена обмана доверчивого исполина злобным карликом. Как тут не вспоминать, что только коварством и почти сверхъестественным напряжением злой воли смог сын бедного корсиканского адвоката занять престол самой могущественной из европейских королевских династий. Такое деяние казалось магией и колдовством для многих современников.

Злодей в глубокой тишине, Пристав, на цыпочках ко мне Подкрался сзади, размахнулся:

Как вихорь свистнул острый меч, И прежде, чем я оглянулся, Уж голова слетела с плеч И сверхъестественная сила В ней жизни дух остановила.

Остановила для того, чтобы дождаться героя, способного отомстить убийце, рассказать ему свою повесть и вручить волшебный меч, то есть возможность и право мщения. 
${ }^{20}$ Пушкин А. С. Полн. собр. соч. Т. 4. С. 57.

О витязь! Ты храним судьбою,

Возьми его, и Бог с тобою!

Быть может, на своем пути

Ты карлу-чародея встретишь -

Ах, если ты его заметишь,

Коварству, злобе отомсти!

И наконец я счастлив буду,

Спокойно мир оставлю сей -

И в благодарности моей

Твою пощечину забуду ${ }^{21}$.

Действительно, мог ли оставаться спокоен дух казненного короля, пока его престол занимал безвестный узурпатор?!

Образ Черномора в пушкинской поэме, возможно, самый прозрачный намек автора на историческое лицо (и намек, сделанный еще при жизни этого лица). Наполеона вся Европа знала как уроженца маленького острова посреди Средиземного моря. Одно из самых распространенных его прозвищ (если не самое распространенное!) - это «корсиканский злодей» («бандит», «пират»!) либо просто «корсиканец». Когда в Лицее Пушкин задумывал «Руслана и Людмилу», а это было после встречи на экзамене с автором «Колесницы» (!), Наполеон, потерпевший ряд поражений, находился уже на острове Эльба (опять остров!). Пушкин посвящает этому событию стихотворение «Наполеон на Эльбе», где есть строки:

Прейду я к вам сквозь черные пучины

И гряну вновь погибельной грозой!

«Корсиканский злодей» на троне французских 
королей, опутавший сетью дипломатических интриг всю европейскую политику (как волшебной бородой), «роста самого смешного» (маленький рост Бонапарта поражал современников и вошел в пословицу), «красавиц давний похититель» (опять аналогия с пушкинским текстом!), то есть похититель европейских тронов для своих многочисленных корсиканских родственников, а, кроме того, на самом деле - похититель принцессы МарииЛуизы из дома Габсбургов, которую он получил в жены путем военной и политической угрозы ее отцу, австрийскому императору, - список примет, роднящий Черномора из поэмы Пушкина и родоначальника новой династии французских королей, очень велик.

\footnotetext{
${ }^{21}$ Там же. С. 58.
}

262

Среди первых читателей «Руслана и Людмилы» (а Пушкин в первой строфе «Евгения Онегина» называет их друзьями своих героев), думается, были более проницательные, нежели наивный «житель Бутырской стороны» или неизвестный педант, задавший автору множество глубокомысленных вопросов. Вероятно, для современников предельно красноречиво звучало и название балетного спектакля, поставленного балетмейстером Адамом Глушковским в 1821 году«Руслан и Людмила, или Низвержение Черномора, злого волшебника».

А проницательнее всех, кажется, был поэт, совсем недавно слагавший в честь побед русского оружия стихи, - В. А. Жуковский! Отсюда надпись на подаренном портрете, слова которой еще дышат только что отшумевшей военной грозой:

Победителю ученику от побежденного учителя в тот 
высокоторжественный день, когда он окончил «Руслана и Людмилу»...

Так выражался «певец во стане русских воинов», обращаясь к поэту, о котором он еще недавно отзывался в письме к П. А. Вяземскому:

Это надежда нашей словестности...

Руслан, герой первой прославленной пушкинской поэмы (очень впечатляет созвучие его имени с названием России на немецком языке - Russland - это имя во время наполеоновских войн повсеместно звучало в Европе), оказывается именно тем мстителем за коварное убийство и узурпацию власти, которому суждено было найти волшебный меч, скрытый под отрубленной головой великана. Но пуститься в путь российского богатыря побуждает отнюдь не желание отомстить за неведомого еще ему тогда страдальца. Он сам страшно пострадал от коварного волшебника, в брачную ночь отнявшего у него любимую супругу.

Идя путем определения исторических аналогий с сюжетом поэмы, неизбежно приходишь к предположению, что в образе Руслана мог быть представлен тот юный государь, который взошел на трон в самый разгар бушевавших в Европе наполеоновских войн и которого восхищенные современники именовали Александром Благословенным, Освободителем Европы, а Пушкин назвал «нашим храбрым царем», «нашим Агемемноном» и посвятил ему в лицейские годы большое стихотворение «Александру».

Этот прославленный правитель, блистающий красотой, мужеством, кротостью, поистине был кумиром всех в «прекрасное начало» своих дней на русском престоле. Наполеон, вступивший в древнюю Москву, вторгся в 
заветные пределы, к соборам Кремля, где венчался на царство юный Александр, - и был наказан за это: в реальности разгромом своих армий и распадом созданной им империи, а в русской литературе - низвержением Черномора, злого разбойника в поэме Александра Пушкина «Руслан и Людмила». 